Article

\title{
Determination of Algae and Macrophyte Species Distribution in Three Wastewater Stabilization Ponds Using Metagenomics Analysis
}

\section{Jack Wallace ${ }^{1}$, Pascale Champagne ${ }^{1, \dagger, *}$, Geof Hall ${ }^{1, \dagger}$, Zhaochu Yin ${ }^{2, \dagger}$ and Xudong Liu ${ }^{2, \dagger}$}

1 Department of Civil Engineering, Queen's University, Ellis Hall, 58 University Avenue, Kingston, ON K7L 3N6, Canada; E-Mails: jrwallace@craworld.com (J.W.); gh26@queensu.ca (G.H.)

2 Queen's University Genomics Lab at Ongwanada, Ongwanada Resource Centre, 191 Portsmouth Avenue, Kingston, ON K7M 8A6, Canada; E-Mails: yinzhaochu@gmail.com (Z.Y.); liux@queensu.ca (X.L.)

$\dagger$ These authors contributed equally to this work.

* Author to whom correspondence should be addressed; E-Mail: champagne@civil.queensu.ca; Tel.: +1-613-533-3053; Fax: +1-613-533-2128.

Academic Editor: Kevin Strychar

Received: 31 January 2015 / Accepted: 10 June 2015 / Published: 25 June 2015

\begin{abstract}
This study involved the evaluation of algae and macrophyte species distributions in three wastewater stabilization ponds (WSPs) at a wastewater treatment plant in Ontario, Canada, which has experienced high $\mathrm{pH}$ levels at the final effluent and excessive algae growth during the summer since 2003. From samples collected from the system, the relative abundances of specific algae and aquatic plant (macrophyte) taxa were assessed and correlated to water chemistry data. A strong shift from the dominance of green algae, chlorophyceae, in WSP\#2, to the dominance of aquatic macrophytes, embryophyta, in WSP\#4, was observed and corresponded to field observations. Correlation of the abundances to nutrient parameters suggested that the macronutrient rich conditions in WSP\#2 allowed floating green algae to proliferate against macrophytes. In WSP\#1 and WSP\#4, macrophytes competed against algae and thrived, due to their adaptability to lower nutrient conditions. The $\mathrm{pH}$ increases occurred primarily in WSP\#2 and were not buffered or reduced in WSP\#1 and WSP\#4. Two alternatives strategies for $\mathrm{pH}$ control were recommended for the system: decreasing algae growth in WSP\#2 through duckweed
\end{abstract}


seeding or macronutrient loading reduction; or designing and implementing a constructed wetland $(\mathrm{CW})$ in WSP\#4 with soil and vegetation to buffer $\mathrm{pH}$ prior to release.

Keywords: algae; lagoons; macrophytes; metagenomics; wastewater

\section{Introduction}

Algae play an essential role in aquatic ecosystems, providing the conditions needed for other forms of life by producing oxygen, removing and converting $\mathrm{N}$ and $\mathrm{P}$ from water, and exchanging inorganic carbon with the atmosphere and aquatic system. They are rapidly growing and adaptable eukaryotic photoautotrophs consisting of an estimated 72,500 species, classified into 15 recognized phyla [1,2]. In many aquatic systems, nutrient loadings from agricultural runoff and human wastes can reach elevated concentrations, causing rapid and excessive eutrophication in receiving environments. The causes and effects of this process are well known and documented in aquatic systems, but research on algae growth in naturalized wastewater treatment systems is generally focused on their effect on treatment performance [3-6]. By understanding the species profile and distribution during algal blooms in open systems, a tailored approach to controlling these blooms may be developed [7]. Within naturalized wastewater treatment systems such as wastewater stabilization ponds (WSPs), this would require maintaining a balance between supporting desired algae growth for nutrient removal and oxygen production, and limiting excessive algae growth, which can lead to increases in $\mathrm{pH}$, limit the effectiveness of aerobic oxidation by bacteria, and prevent light and energy penetration to the lower depths of the water column [8-11].

As part of an ongoing performance evaluation of an operating WSP system, this study examined algal and aquatic plant (macrophyte) species profiles and distributions within three WSPs during the summer season through metagenomics sequencing. The WSPs are part of the Amherstview Water Pollution Control Plant (WPCP), operated by Loyalist Township in eastern Ontario, Canada. Since 2003, the WSPs have exhibited excessive algal blooms, which have led to a number of final system effluent $\mathrm{pH}$ level events above the regulatory limit. The aim of this investigation was to correlate the abundance of specific algal and macrophyte taxa to underlying water chemistry conditions, and to provide information that would assist in the development of a tailored approach for controlling algae levels and $\mathrm{pH}$ fluctuations, while maintaining acceptable nutrient, total suspended solids (TSS), and carbonaceous biochemical oxygen demand (cBOD) removals. Over a three-month period, from mid-summer into early fall, floating plant biomass and surrounding water samples were collected from the WSPs and analyzed using DNA metagenomics sequencing to determine the relative abundances of algal and macrophyte taxa. Results were then correlated to water chemistry data containing a wide range of parameters, also collected over the monitoring period. 


\section{Materials and Methods (or Experimental)}

\subsection{System Overview}

In this study, algal and macrophyte biomass, as well as water samples, were collected from July to September 2012 from three WSPs at the WPCP to identify the predominant algal and macrophyte species and their distribution throughout the system. The WSPs were constructed separately starting in 1964, with the addition of a direct activated sludge process in 1996 (main wastewater treatment plant). All WSPs were designed as facultative systems for polishing, disinfection and stabilization of municipal wastewater [12]. The main wastewater treatment plant effluent (PL) feeds into WSP\#2, followed by WSP\#1, and then WSP\#4, which is the final effluent point. Table 1 summarizes the design surface areas, volumes, and depths of the WSPs based on field measurements performed in the summer of 2012. They are numbered as 2, 1 , and 4 in order of flow due to historical changes in the treatment configuration, and have surface areas of 48,600 $\mathrm{m}^{2}, 28,200 \mathrm{~m}^{2}$, and 31,200 $\mathrm{m}^{2}$, respectively (Table 1).

Table 1. Area, volume, and depth of the Amherstview Water Pollution Control Plant (WPCP) wastewater stabilization ponds (WSPs) based on field measurements performed in the summer of 2012.

\begin{tabular}{cccc}
\hline WSP & Surface Area $\left(\mathbf{m}^{\mathbf{2}}\right)$ & Volume $\left(\mathbf{m}^{\mathbf{3}}\right)$ & Depth $(\mathbf{m})$ \\
\hline 2 & 48,600 & 78,246 & 1.61 \\
1 & 28,200 & 40,044 & 1.42 \\
4 & 31,200 & 36,504 & 1.17 \\
Total & 108,000 & 154,794 & 4.2 \\
\hline
\end{tabular}

\subsection{Field Sampling and Chemical Analysis}

A total of 17 grab samples of floating and suspended plant biomass and surrounding water were collected together in $250 \mathrm{~mL}$ low-density polyethylene (LDPE) bottles and stored on ice until delivery to the Queen's University laboratory, where they were freeze dried and stored below $0{ }^{\circ} \mathrm{C}$ until analysis. Samples were collected between 10 a.m. and 12 p.m., which generally corresponded to rising daily temperature and solar radiation conditions. It should be noted that samples were collected based on site accessibility at the time of sampling, and taken from areas of the WSPs where plant biomass was observed.

DNA from the algal community of biomass samples were purified using the Qiagen DNeasy Plant Mini Kit [13] for DNA isolation. Briefly, whole biomass samples were homogenized using a blender for $30 \mathrm{~s}$, from which a $1 \mathrm{~mL}$ of aliquot was used for DNA extraction. The aliquots were frozen for $30 \mathrm{~s}$ in liquid $\mathrm{N}$ and then disrupted using the Tissue Lyser (LT) set at $50 \mathrm{~Hz}$ for $30 \mathrm{~s}$. This process was repeated twice. DNA was extracted from the aliquots and purified according to the Qiagen DNeasy Plant Mini Kit. The extracted DNA samples were quantified for concentration using a UV spectrophotometer and the genomic DNA quality was verified with a $1 \%$ agarose gel conducted for DNA integrity. Targeted metagenomics analysis was performed on the $18 \mathrm{~S}$ RNA gene, noted to be a commonly used target in universal primers, using barcoded fusion polymerase chain reaction (PCR) [14]. It has been reported that $18 \mathrm{~S}$ sequencing can capture all phototrophic eukaryotes, but must 
span a large diversity and cannot target cyanobacteria [15]. 16S sequencing, the other commonly used target, captures cyanobacteria at high frequencies. As cyanobacteria were not detected in the WSP effluents with fluorometric methods, and as the focus of this study was on eukaryotes, 18S was deemed the more appropriate target as employed in other recent genomic studies of this nature [16-20]. The primers used for PCR amplification are presented in Table 2. The conditions under which PCR was conducted are presented in Table 3. Purification of amplified PCR product was performed using Beckman Ampure Beads. This procedure removed primer dimers and free adapters. Quantification and purity of amplified PCR products were assessed with Agilent 2100 Bioanalyzer-DNA High Sensitivity reagents and chips.

Table 2. Forward and reverse primers applied for $18 \mathrm{~S}$ RNA gene sequencing in metagenomics analysis of the samples collected from the WSPs.

\begin{tabular}{cc}
\hline Primer & Sequence \\
\hline Forward-A18s-P47 (barcodes 1-10) & 5'-TCTCAGGCTCCCTCTCCGGA-3' \\
Reverse-A18s-P73 & 5'-AATCAGTTATAGTTTATTTGRTGGTACC-3' \\
\hline
\end{tabular}

Table 3. PCR phase conditions applied in metagenomics analysis of the samples collected from the WSPs.

\begin{tabular}{ccc}
\hline Temperature & Time Period & Cycles \\
\hline $94{ }^{\circ} \mathrm{C}$ & $5 \mathrm{~min}$ & 1 \\
$94{ }^{\circ} \mathrm{C}$ & $30 \mathrm{~s}$ & $15-26$ \\
$55^{\circ} \mathrm{C}$ & $30 \mathrm{~s}$ & $15-26$ \\
$72{ }^{\circ} \mathrm{C}$ & $30 \mathrm{~s}$ & $15-26$ \\
$72{ }^{\circ} \mathrm{C}$ & $5 \mathrm{~min}$ & 1 \\
$4{ }^{\circ} \mathrm{C}$ & To end of PCR & 1 \\
\hline
\end{tabular}

Metagenomic sequencing was performed using Ion Torrent Personal Genomic Machine (PGM) with 318 Chips. Briefly, sequencing template preparation for 316 chips run was performed on Ion Torrent One-Touch System I using emulsion PCR to amplify the fragments and bind them to sequencing beads following the Ion PGM Template OT2 200 Kit protocol [21]. Then the templates were subjected to a sequencing run on the Ion PGM instrument using the 316 chips following the Ion PGM Sequencing $200 \mathrm{Kit}$ protocol [22]. The sequencing was undertaken in two batches, with 12 samples for each pool using the sample barcoding strategy.

\subsection{Water Chemistry}

Water chemistry samples for the determination of correlations to metagenomics data was collected from the WSPs on the same dates as those collected for the metagenomics analysis. Samples were taken from 0 to 1 meters below the surface of the water. Fluorometric determination of chlorophyll-a (chl-a), as an indicator of green algae, was performed with a Hydrolab DS5 probe (Turner Designs Cyclops). Key water quality indicators consisted of $\mathrm{pH}$ and temperature measured with a Hach HQ40D probe; dissolved oxygen (DO) measured with an Aysix 3100 probe, alkalinity and TSS determined in the laboratory using American Public Health Association (APHA) [23] Methods 2320B and APHA 
2540D, respectively; as well as conductivity and oxidation reduction potential (ORP) measured with a Hydrolab DS5 sonde. Ground solar insolation data for the area from NASA was also monitored (NASA, 2012). Nitrogenous species (ammonium $\left(\mathrm{NH}_{4}^{+}\right)$, unionized ammonia $\left(\mathrm{NH}_{3}\right)$, total Kjeldahl nitrogen $(\mathrm{TKN})$ for determination of organic nitrogen, nitrate $\left(\mathrm{NO}_{3}^{-}\right)$, and nitrite $\left(\mathrm{NO}_{2}^{-}\right)$) were determined in the laboratory using APHA Method 4500-NH3-H, and Ontario Ministry of Environment and Energy (MOEE) Method E3199A.1, APHA 4110C, and APHA 4110C, respectively. Total and reactive phosphorus (orthophosphate) species were determined in the laboratory using MOEE Method E3199A.1 and APHA 4500PE/Hach Method 8048, respectively. The cBOD5 and chemical oxygen demand (COD) species were determined in the laboratory using APHA 5210B and APHA $5220 \mathrm{D} /$ Hach 8000 , respectively.

\subsection{Statistical Analysis}

The metagenomics sequencing data was analyzed using the Metagenomics Analysis Pipeline established mainly based on the QIIME package [24]. The results of the sequencing are presented by relative abundance of the algae and macrophytes detected for each sample and expressed as a percentage of the total amount of sample collected, for each taxonomic level (i.e., order, class). Taxonomic levels were divided into increasing depth down to the level of order. Relative abundances for individual samples were related to the sampling location and date graphically to provide visual representation of growth dynamics. A phylogenetic tree was elaborated through hierarchal cluster analysis and weighted unifrac distances were calculated according to the methods presented by other researchers [25]. Performing principal coordinate analysis (PCoA) on unifrac distances was recommended by researchers [26] to retrieve significant graphic patterns from sequencing data. PCoA was applied to the weighted unifrac distances to graphically represent the similarities between samples for the first three principal coordinate (PCo) axes. PCoA is a similar procedure to PCA, but attempts to highlight similarities between cases (individual samples), where PCA highlights patterns in samples [27]. Correlations between the metagenomics and water chemistry were calculated for sampling events where both metagenomics and water chemistry were available, using SASC $\mathrm{JMP}^{\circledR}$ 10.0.0 software. Due to the non-parametric nature of the data, the Spearman $\rho$ correlation coefficient was evaluated for the initial multivariate correlations instead of the Pearson $r$ correlation coefficient.

\section{Results}

\subsection{Distribution and Abundance}

The relative abundances of algae and macrophytes for each sample are represented spatially and temporally in Figure 1 and photographs of the WSPs on selected sampling dates are shown spatially in Figure 2. Samples collected from the shores of the WSPs are indicated. The predominance of two taxonomic levels was observed throughout the monitoring period and WSPs: Chlorophyta chlorophyceae and streptophyta embryophyta. Chlorophyceae is a taxonomic class containing the majority of green algae; from field observations it was apparent that both macro-algae species, distinguished by large groupings of biomass, and micro-algae species, distinguished by the chlorophyll levels in the water, were present in the system. Embryophyta is a subkingdom otherwise known as land plants including 
all terrestrial plants and many aquatic plants [28]. Chlorophyceae, embryophyta were detected the most often and, hence, the focus of the study. Trebouxiophyceae was detected on a relatively minor level, while all other eukaryotic organisms detected were categorized as "other" to provide focus to the analysis. Common aquatic plants observed in the WSPs that are classified as embryophyta include the milfoil genus [29], duckweed subfamily [30], and pondweed family [31]. The three groups are vascular plants, in contrast to the simpler physiological structure of green algae chlorophyta, which do not contain vascular tissues [28]. No patterns were observed in the relative abundance percentages with time (Figure 1), indicating a relatively consistent species distribution for each WSP over the monitoring period.

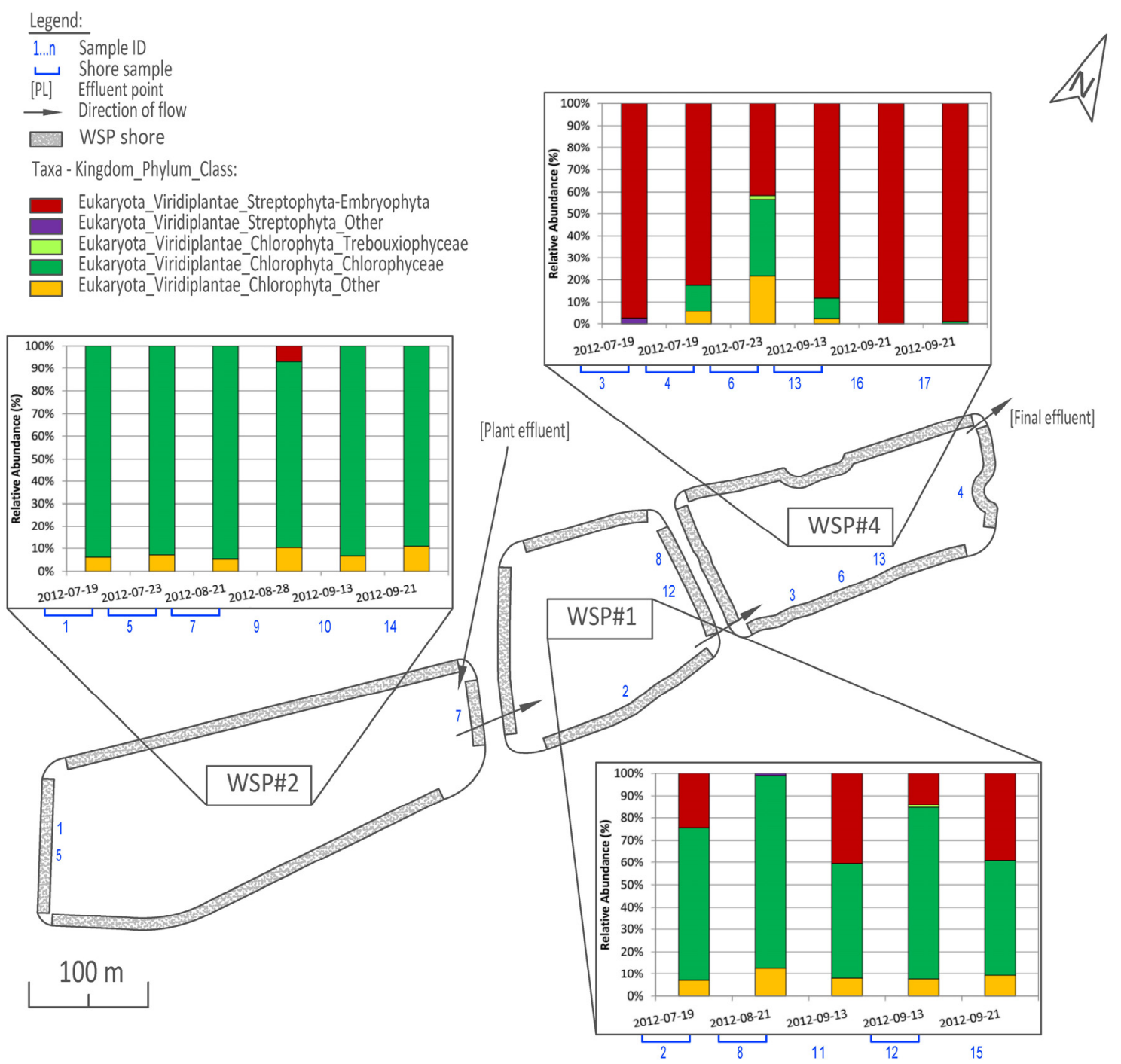

Figure 1. Spatial and temporal representation of the relative abundance of eukaryotic species in the WSPs at the Amherstview WPCP over the July to September 2012 sampling period.

Chlorophyta was dominant in all WSP\#2 samples, with relative abundance values above 90\%. In WSP\#1, chlorophyta remained the dominant order, with values above $50 \%$ for all samples, but embryophyta was also observed, with abundances ranging between $0 \%$ and $40 \%$. In WSP\#4, embryophyta was dominant with abundances above $80 \%$ in all samples except one obtained from the south shore, which contained a mixture of embryophyta, chlorophyta, and other eukaryotic organisms. 


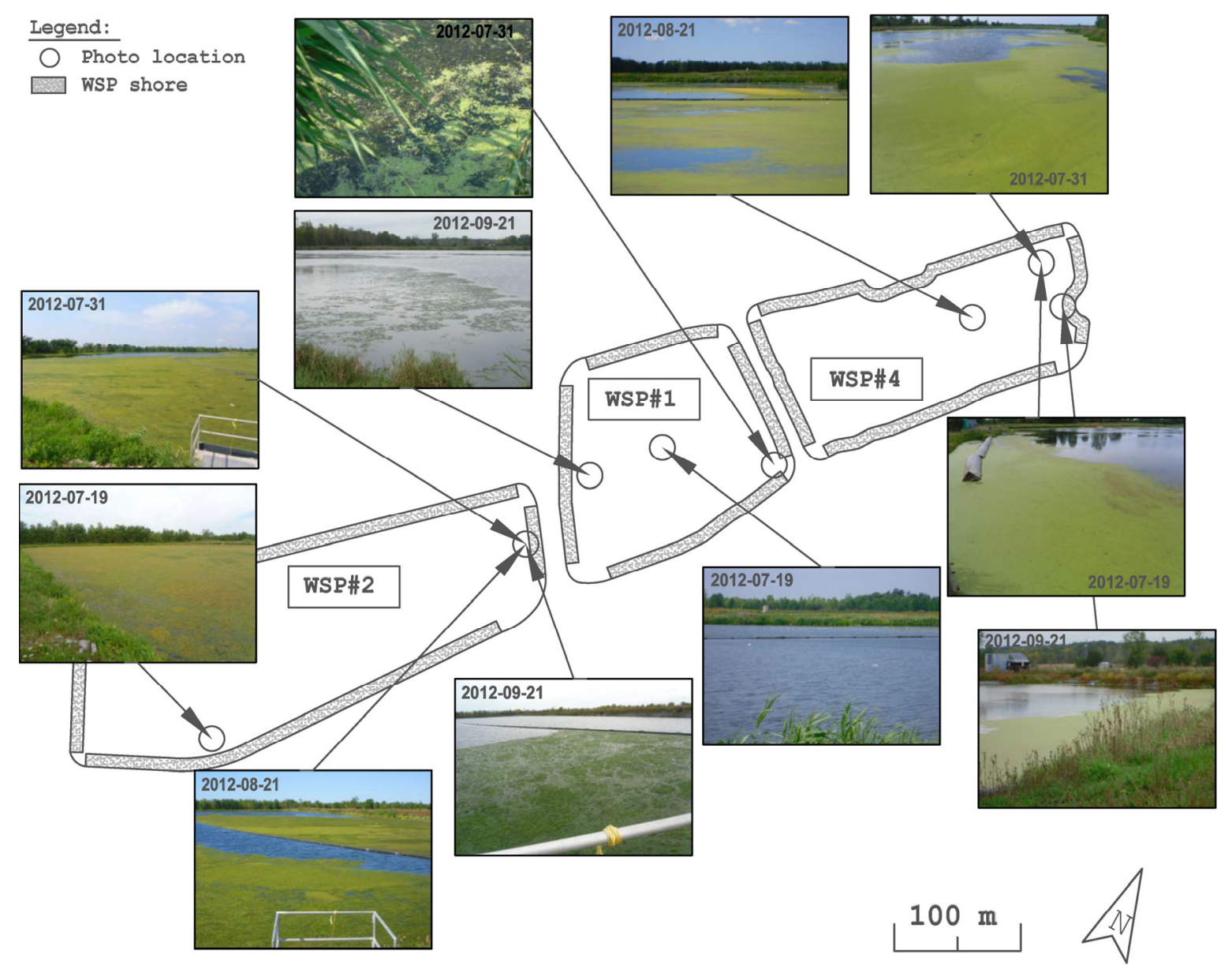

Figure 2. Site photographs taken throughout the sampling period for each WSP over a range of dates in the July to September 2012 sampling period at the Amherstview WPCP, with photograph locations indicated.

\subsection{Cluster and PCoA Analysis of Samples}

Weighted unifrac and cluster analysis and PCoA plots presented in Figures 3 and 4, respectively, confirm the relationships and similarities between the species abundances observed in the samples. The WSPs were well separated by hierarchal clustering, as seen by the tree structure for the system (Figure 3). The branched clusterings of WSP\#2 and WSP\#1 samples together and WSP\#4 samples separately (Figure 3 ) correspond to the relative abundance percentages observed and the associated taxa levels (Figure 1). Three samples dissimilar to the others were noted from the PCoA plots (Figure 4), where they are shown to be isolated from the main clusters of the samples on the PCoA plots. In the PCo1 vs. PCo2 plot (Figure 4a), the WSP\#4 samples (triangle) at the top and bottom are noted to stray from the PCo2 $(x)$ axis. In the PCo2 vs. PCo3 plot (Figure 4b), these two WSP\#4 samples and a WSP\#1 sample are noted to lie to the left of the main cluster. In the PCo1 vs. PCo3 plot (Figure 4c), all three are noted to lie below the main cluster of samples. These three samples were taken from the shore, which may have contributed to their different compositions, as sludge and other organic matter was more likely to be present due to shallow water lesvels and proximity to shorelines. 


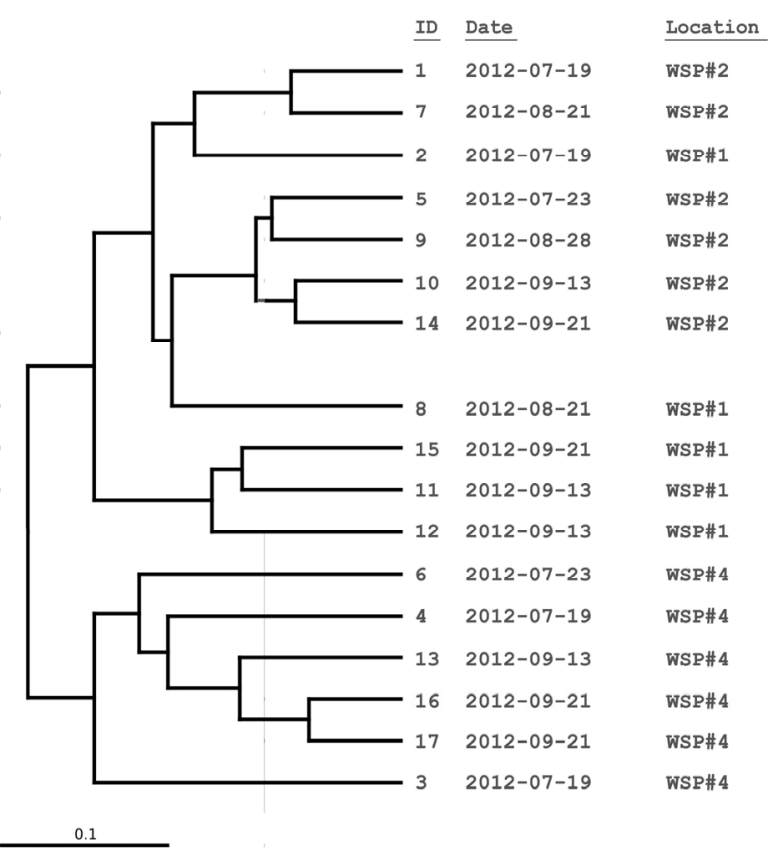

Figure 3. Hierarchal cluster analysis of samples based on diversities of the relative abundances, showing strong clustering of WSP\#2 in one branch and WSP\#1 and WSP\#4 in another, and supporting the relative abundances observed in Figure 1.

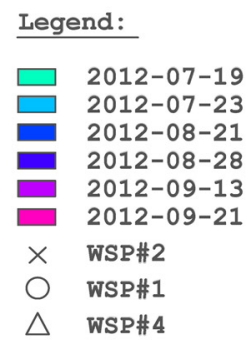

(b) $\mathrm{PCOA}-\mathrm{PCO}$ vs $\mathrm{PCO} 2$

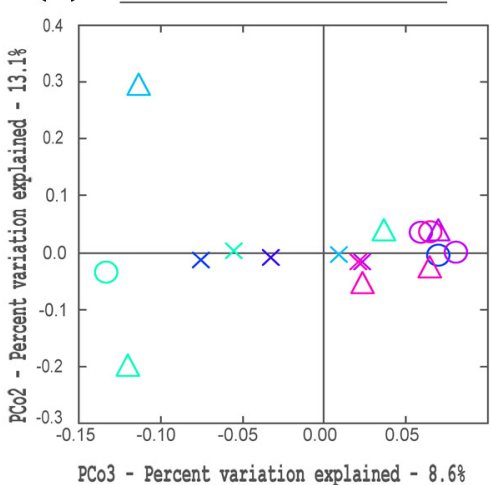

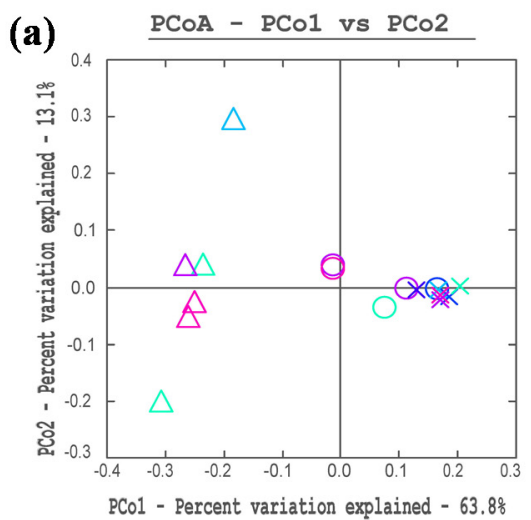

(c) $\quad$ PCOA - PCO1 vs $\mathrm{PCO} 3$

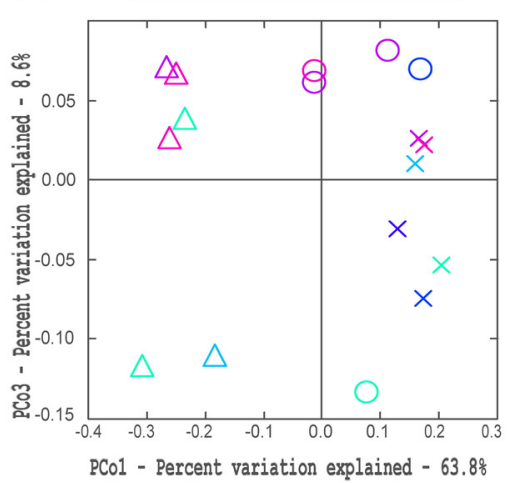

Figure 4. PCoA plots of the samples for the first three principal coordinates of the PCoA analysis, with colour indicating sample data and shape indicating sample location; (a) PCo1 vs. PCo2 plot; (b) PCo3 vs. PCo2 plot; (c) PCo1 vs. PCo3 plot; three outliers-two from WSP\#4 and one from WSP\#1 - are observed and correspond to samples taken from the shore. 


\subsection{Water Chemistry Conditions and Monod Growth Model}

To illustrate spatial water chemistry trends, a summary of the WSP system water chemistry parameters is presented in Table 4, represented as the mean values over the sampling period with standard deviations, as well as the overall average percent change over all WSPs, for each parameter.

A Monod growth model derived for the WSPs from chl-a and substrate concentration measurements was developed, as has been performed by other researchers [30]. The model estimated nutrient requirements for WSP\#2 to be up to $0.021 \mathrm{mg} / \mathrm{L}$ of dissolved inorganic $\mathrm{N}$ (DIN) and $0.0040 \mathrm{mg} / \mathrm{L}$ of total $\mathrm{P}$, while measurements indicated average concentrations of $1.2 \mathrm{mg} / \mathrm{L} \mathrm{DIN}$ and $0.13 \mathrm{mg} / \mathrm{L}$ total $\mathrm{P}$, suggesting that nutrients in the WSP were available in excess by over $1.2 \mathrm{mg} / \mathrm{L} \mathrm{DIN}(5700 \%)$ and over $0.13 \mathrm{mg} / \mathrm{L}$ total P (3200\%). Monod growth models are suitable for modelling algae growth and have been used in a number of studies [9,32-34].

Table 4. Summary of system water chemistry parameters, with average values over the sampling period and percent change values across the WSP system over the July to September sampling period.

\begin{tabular}{|c|c|c|c|c|c|}
\hline \multirow{2}{*}{ Parameter } & \multicolumn{4}{|c|}{ Average Values } & \multirow{2}{*}{$\begin{array}{c}\text { Overall Percent } \\
\text { Change }\end{array}$} \\
\hline & PL & WSP\#2 & WSP\#1 & WSP\#4 & \\
\hline Chlorophyll-a & $2.1 \pm 0.56$ & $2.4 \pm 1.4$ & $5.6 \pm 7.5$ & $4.8 \pm 3.5$ & $132 \%$ \\
\hline $\mathrm{pH}$ & $7 \pm 0.18$ & $9.5 \pm 0.46$ & $9.4 \pm 0.78$ & $9.6 \pm 0.7$ & $37 \%$ \\
\hline Temperature & $19 \pm 2.1$ & $21 \pm 4.9$ & $21 \pm 5.3$ & $21 \pm 4.9$ & $7 \%$ \\
\hline Dissolved oxygen & $3.6 \pm 1.3$ & $9.2 \pm 3.8$ & $7.4 \pm 3.7$ & $7 \pm 3.5$ & $97 \%$ \\
\hline Alkalinity & $96 \pm 31$ & $120 \pm 23$ & $120 \pm 14$ & $120 \pm 17$ & $30 \%$ \\
\hline Conductivity & $660 \pm 53$ & $600 \pm 41$ & $600 \pm 43$ & $580 \pm 79$ & $-12 \%$ \\
\hline Oxidation Reduction Potential & $180 \pm 63$ & $120 \pm 86$ & $120 \pm 76$ & $67 \pm 120$ & $-62 \%$ \\
\hline Total Suspended Solids & $11 \pm 11$ & $1.3 \pm 1.2$ & $3.2 \pm 3$ & $1.9 \pm 1.7$ & $-83 \%$ \\
\hline $\begin{array}{c}\text { Carbonaceous Biochemical } \\
\text { Oxygen Demand }\end{array}$ & $5.3 \pm 3.6$ & $2.2 \pm 0.36$ & $2.6 \pm 0.82$ & $3 \pm 0.79$ & $-44 \%$ \\
\hline Chemical Oxygen Demand & $20 \pm 13$ & $18 \pm 6.1$ & $24 \pm 9.8$ & $24 \pm 8.3$ & $23 \%$ \\
\hline Total Nitrogen & $23 \pm 3.7$ & $6.4 \pm 1.1$ & $3.5 \pm 1.2$ & $2.1 \pm 0.38$ & $-91 \%$ \\
\hline Ammonia & $0.047 \pm 0.065$ & $0.19 \pm 0.15$ & $0.27 \pm 0.37$ & $0.16 \pm 0.21$ & $230 \%$ \\
\hline Unionized Ammonia & $0.005 \pm 0$ & $0.078 \pm 0.056$ & $0.072 \pm 0.088$ & $0.049 \pm 0.05$ & $877 \%$ \\
\hline Nitrate & $21 \pm 3.6$ & $4.9 \pm 2.1$ & $1.9 \pm 1.5$ & $0.5 \pm 0.53$ & $-98 \%$ \\
\hline Nitrite & $0.14 \pm 0.12$ & $0.88 \pm 0.26$ & $0.24 \pm 0.18$ & $0.13 \pm 0.062$ & $-6 \%$ \\
\hline Organic Nitrogen & $1.9 \pm 2.3$ & $1.1 \pm 0.36$ & $1.4 \pm 0.48$ & $1.3 \pm 0.33$ & $-32 \%$ \\
\hline Total Phosphorus & $1 \pm 0.49$ & $0.4 \pm 0.22$ & $0.36 \pm 0.18$ & $0.38 \pm 0.2$ & $-64 \%$ \\
\hline Orthophosphate & $2.4 \pm 1.1$ & $2 \pm 1.5$ & $1.3 \pm 0.91$ & $1.3 \pm 1.4$ & $-44 \%$ \\
\hline
\end{tabular}

\subsection{Correlations to Water Chemistry Parameters}

Spearman rank correlation coefficients were determined between the relative abundances of embryophyta and chlorophyta, and between embrophyta and the water chemistry parameters and then chlorophyta and the water chemistry parameters, to establish the water chemistry conditions preferentially associated with each species class. A Spearman rank correlation coefficient of -0.972 , with a $p$-value $<0.0001$, between the embryophyta and chlorophyceae species classes across all WSPs, 
suggested a strong contrast between their abundance and, thus, confirmed the spatial shift from algae to macrophytes throughout the WSPs. The correlation between embryophyta and trebouxiophyceae was weak due to the limited abundance of this group in the samples. Spearman coefficients between the embryophyta and chlorophyceae groups and water quality parameters are presented in Table 5 . In many cases, embryophyta correlations to macronutrients ( $\mathrm{N}$ and $\mathrm{P}$ species) and organic matter (cBOD and $\mathrm{COD}$ ) had opposite signs than chlorophyceae correlations to these parameters, further contrasting the differences between the two classes and water chemistry conditions.

Table 5. Spearman rank correlation coefficients between embryophyta and chlorophyceae and water chemistry parameters measured at each of the WSP effluents and across all WSPs for the sampling dates, sorted by significance probability statistic (summed $p$-value; smallest to largest).

\begin{tabular}{|c|c|c|c|c|c|c|c|c|}
\hline \multirow{2}{*}{ Effluent Parameter } & \multicolumn{4}{|c|}{ Chlorophyta_Chlorophyceae } & \multicolumn{4}{|c|}{ Streptophyta_Embryophyta } \\
\hline & All WSP & WSP\#2 & WSP\#1 & WSP\#4 & All WSP & WSP\#2 & WSP\#1 & WSP\#4 \\
\hline Orthophosphate & 0.78 & -0.49 & 0.67 & 0.48 & -0.84 & 0.65 & -0.67 & -0.29 \\
\hline Organic nitrogen & -0.27 & -0.37 & 0.56 & 0.63 & 0.16 & 0.65 & -0.56 & -0.88 \\
\hline $\begin{array}{c}\text { Carbonaceous biochemical } \\
\text { oxygen demand }\end{array}$ & 0.38 & 0.65 & 0.67 & 0.39 & -0.43 & -0.20 & -0.67 & -0.15 \\
\hline Nitrate & 0.61 & 0.46 & -0.46 & -0.48 & -0.54 & 0.13 & 0.46 & 0.29 \\
\hline Dissolved oxygen & 0.16 & -0.09 & -0.67 & -0.63 & -0.07 & -0.65 & 0.67 & 0.88 \\
\hline Total nitrogen & 0.57 & 0.14 & -0.46 & 0.20 & -0.53 & 0.39 & 0.46 & -0.52 \\
\hline Total phosphorus & 0.28 & -0.26 & 0.46 & 0.30 & -0.38 & 0.13 & -0.46 & -0.65 \\
\hline Nitrite & 0.42 & -0.26 & -0.46 & -0.42 & -0.39 & 0.13 & 0.46 & 0.24 \\
\hline Nitrogen/Phosphorus Ratio & 0.13 & 0.31 & -0.56 & -0.63 & 0.04 & -0.13 & 0.56 & 0.88 \\
\hline Chlorophyll-a & -0.19 & 0.71 & 0.05 & 0.30 & 0.14 & -0.65 & -0.05 & -0.65 \\
\hline Chemical oxygen demand & 0.05 & 0.66 & 0.05 & 0.63 & -0.08 & -0.39 & -0.05 & -0.88 \\
\hline Unionized ammonia & 0.21 & 0.20 & -0.22 & 0.09 & -0.23 & -0.65 & 0.22 & -0.35 \\
\hline $\mathrm{pH}$ & 0.02 & -0.60 & -0.45 & -0.30 & 0.01 & -0.13 & 0.45 & 0.65 \\
\hline Ammonia & 0.09 & 0.09 & -0.36 & 0.30 & -0.11 & 0.13 & 0.36 & -0.65 \\
\hline
\end{tabular}

The correlations to orthophosphate and organic $\mathrm{N}$ were found to be negative in WSP\#2 and positive in WSP\#1 and WSP\#4 for chlorophyceae, while they were positive for embryophyta. Orthophosphate is the readily available form of $\mathrm{P}$ for uptake by algae and macrophytes [9,35,36], and the negative correlations to the abundances of each species class in the WSPs in which they were most abundant suggests that orthophosphate was readily uptaken. Organic $\mathrm{N}$ was continuously consumed and released by algae [37], and the negative correlations to chlorophyceae and embryophyta abundances suggest that, as with orthophosphate, it was readily uptaken. DO was noted to be strongly negatively correlated to chlorophyceae and strongly positively correlated to embryophyta in WSP\#1 and WSP\#4, highlighting the role that the macrophytes likely exhibited in producing DO. Dynamic time lags between DO, chl-a, and pH were previously determined in another study [38] as the likely cause of negative correlations between these parameters, were that the fluctuations in these parameters were offset by a certain period of time. Hence, the negative correlations between these parameters and chlorophyceae abundance may be due to these dynamic time lags. 


\section{Discussion}

In spatial terms, a strong shift from green algae dominating the growth conditions in WSP\#2 to the introduction of macrophytes in WSP\#1 and then the predominance of aquatic plants in WSP\#4 was noted in this WSP system (Figure 1). This spatial shift corresponds well with field observations throughout the monitoring period. The positive correlation between chlorophyceae and chl-a was noted to be strong for WSP\#2, but not for the other WSPs. Additionally, there were strong negative correlations between embryophyta and chl-a in all WSPs (Table 5). These trends confirmed that the chl-a measurements in the WSPs were most likely the result of green algae abundance in WSP\#2, including suspended material, and not by the abundance of macrophytes. High levels of floating green algae were present in WSP\#2 throughout the monitoring period (Figure 2), with gradual die-off occurring as temperatures decreased in September. The floating algae may have prevented the growth of other aquatic plants, such as milfoil and duckweed, in WSP\#2 as sunlight penetration would have been limited at the lower depths of the water column. In WSP\#1, the presence of floating algae was sparser, allowing for more sufficient light penetration and for macrophyte plant growth, as noted by the corresponding milfoil growth observed throughout the monitoring period (Figure 2). It is likely that reasonable light penetration and the lower availability of macronutrients compared with WSP\#2 prevented the dominance of either classes of species and allowed for the establishment of both chlorophya and embryophyta. In WSP\#4, the dominance of macrophytes, particularly duckweed, was observed throughout the study (Figure 2). Green algae were observed in small agglomerations across the WSP surface.

A more detailed breakdown of the embryophyta class was not obtained from the sequencing. Three major types were most easily recognized during field observations throughout the study: milfoil (myrophyllum), duckweed (lemna), and pondweed (potamogeton) (Figure 2) [28]. From WSP\#2 through to WSP\#4, growth conditions changed from the predominance of simple green plants, consisting primarily of chlorophyta (green algae), to more complex macrophytes within the subkingdom of embryophyta containing vascular tissues (Figure 1). The concentrations of N and P, availability of sunlight, and other factors such as $\mathrm{pH}$ and temperature in the individual WSPs (Table 4) likely favoured the algae and macrophyte compositions observed in each of the WSPs.

Green algae have been noted to perform photosynthesis more efficiently than macrophytes, with efficiencies between $0.5 \%$ and $6.0 \%$ [10] compared to $0.1 \%-2.0 \%$ [39], respectively. Growth rates for algae and macrophytes reported in literature were compared to assess which would be more likely to grow rapidly and dominate WSP\#2 as this WSP contained the highest macronutrient concentrations (Table 4). Of the macrophytes observed in the WSPs, duckweed was expected to be the fastest growing plant. Duckweed is known to grow very rapidly; where under the appropriate conditions an agglomeration may double its biomass in two days, making them among the fastest growing aquatic angiosperms in the world and comparable to the fastest terrestrial plants [32,40,41]. The specific growth rate $\left(\mu, \mathrm{d}^{-1}\right)$ for the Monod equation has been utilized as a metric for algae and duckweed growth by a number of researchers [32-34]. $\mu$ values from 0.8 to $1.07 \mathrm{~d}^{-1}$ for algae grown in nutrient enriched water (up to $2 \mathrm{mg} / \mathrm{L}$ total $\mathrm{N}$ and $1 \mathrm{mg} / \mathrm{L}$ total $\mathrm{P}$ added) from two reservoirs, maintained at an average temperature of $28-30{ }^{\circ} \mathrm{C}$, have been reported [33]. Similarly, $\mu$ values from 0.35 to $0.48 \mathrm{~d}^{-1}$ for algae grown in nutrient enriched water $\left(500 \mathrm{mg} / \mathrm{L}\left(\mathrm{NH}_{4}\right)_{2} \mathrm{SO}_{4}, 500 \mathrm{mg} / \mathrm{L} \mathrm{KNO}\right.$, and $100 \mathrm{mg} / \mathrm{L}$ $\mathrm{KH}_{2} \mathrm{PO}_{4}$ added) from the inlet of a facultative WSP, maintained at an average temperature of $30{ }^{\circ} \mathrm{C}$, have 
been reported [34]. Conversely, $\mu$ values from 0.16 to $0.22 \mathrm{~d}^{-1}$ for duckweed grown in cattle feedlot runoff wastewater (containing $329 \mathrm{mg} / \mathrm{L}$ total $\mathrm{N}$ and $231 \mathrm{mg} / \mathrm{L}$ orthophosphate), maintained at an average temperature of $29{ }^{\circ} \mathrm{C}$, have been reported [32]. From these studies, it was noted that algae have higher $\mu$ values than duckweed for all ranges cited.

A previous study conducted by Wallace et al. [38] evaluated the water chemistry conditions within the WSPs, as they related to $\mathrm{pH}$ and chl-a. This study determined strong correlations between chl-a and macronutrients $\mathrm{N}$ and $\mathrm{P}$. Further evaluation of $\mathrm{N}$ and $\mathrm{P}$ in the system, as they relate to the individual algae and macrophyte species, is presented herein. WSP\#2 contained the highest $\mathrm{N}$ and $\mathrm{P}$ loads of the system, as modelled with the Monod growth model, with levels in excess of the amount required for the green algae growth observed. The more rapid algae growth compared to duckweed and other macrophytes observed in the system, would imply that the algae likely out-competed these other plants, thereby establishing and sustaining the large formations of biomass observed in WSP\#2 (Figure 2), until die-off in the fall. The large floating agglomerations of algae in WSP\#2 would also limit sunlight penetration at the lower levels of the water column, where milfoil and pondweed are rooted [42]. $\mathrm{NO}_{3}{ }^{-}$is the principal form of $\mathrm{N}$ that algae can uptake and was most abundant in WSP\#2 followed by large decreases in concentrations in WSP\#1 and WSP\#4 (Table 4) [9]. A strong positive correlation between the chlorophyceae abundance and $\mathrm{NO}_{3}{ }^{-}$concentration was observed in WSP\#2, suggesting that this was the preferred $\mathrm{N}$ form for algae growth in WSP\#2, compared to weak to negative correlations between chlorophyceae abundance and $\mathrm{NO}_{2}^{-}, \mathrm{NH}_{4}{ }^{+}$, and $\mathrm{NH}_{3}$ (Table 4).

In WSP\#1, lower N and P levels (Table 4) likely provided a more balanced opportunity for growth between algae and macrophytes, as observed by the increasing presence of the latter. Additionally, it has been shown that macrophytes draw a significant portion of their $\mathrm{N}$ and $\mathrm{P}$ requirements from sediments [43]. It was reported that sediments were the primary pathway for $\mathrm{N}$ and $\mathrm{P}$ uptake by macrophytes in the majority of natural waters, particularly for lakes and ponds, where flow rates are slow [43,44]. Sediments of WSPs contain high levels of N and P as a result of precipitation and sedimentation [45]. The lower macronutrient levels in the waters of WSP\#1 compared with WSP\#2 likely limited algae growth, but did not hinder the growth of rooted macrophytes such as milfoil and pondweed, as they would be able to meet their macronutrient requirements from the sediment zone.

In WSP\#4, total $\mathrm{N}$ levels decreased further and total P levels remained constant, and the abundance of algae and chl-a levels were both noted to decrease. The abundance of embryophyta increased considerably to levels above $80 \%$. As in WSP\#1, milfoil and pondweed were likely able to access their macronutrient requirements from the sediments. The growth of large agglomerations of duckweed in WSP\#4 may be explained by its tolerance to high $\mathrm{pH}$, where studies have shown that it can sustain growth at $\mathrm{pH}$ levels of up to 9.5-10 [40,46]. Algae, including chlorophyceae, generally grow in a $\mathrm{pH}$ range of 7-9 [47]. While excessive algae growth can cause an increase in $\mathrm{pH}$ levels through the consumption of $\mathrm{CO}_{2}$, high $\mathrm{pH}$ level can also eventually hinder algae growth, even $\mathrm{pH}$ tolerant algae [48]. In one study, researchers noted a reduction in chl-a levels of nearly $90 \%$ for freshwater algae cultures in waters with $\mathrm{pH}$ levels maintained at 8.9 and 9.9, respectively [48]. Once duckweed populations are established during the summer months, they can then limit the growth of algae and consequently reduce the concentration of DO throughout the water column. Unlike algae, duckweed does not transfer oxygen to the water column to sustain aerobic bacterial activity [49]. This 
phenomenon was observed during the study, with DO levels decreasing $19 \%$ and $5 \%$ across WSP\#1 and WSP\#4, respectively.

In terms of $\mathrm{pH}$ levels, WSP\#2 is the main operational concern of this WSP system, as the majority of the $\mathrm{pH}$ fluctuations occur in this system and remain unbuffered in the subsequent WSPs (Figure 5). Increases in $\mathrm{pH}$ resulting from photosynthetic algae growth is well documented [8-10,50]. Over the monitoring period, $\mathrm{pH}$ levels rose a mean of 2.4 (34.0\%) within WSP\#2, compared to an increase of $0.16(1.9 \%)$ in WSP\#1 and an increase of $0.02(0.35 \%)$ in WSP\#4. pH levels were generally lower in WSP\#1 and WSP\#4 from the levels observed in WSP\#2 from mid-July to mid-August (Figure 5), when temperatures were highest. The presence of duckweed has been reported to be associated with decreases in $\mathrm{pH}$ levels [46,51] and may have been a contributing factor in this study. However, the smaller populations of duckweed in WSP\#4 compared to algae in WSP\#2, may have limited the significance of duckweed influence on $\mathrm{pH}$ compared with the larger influence exerted by the excessive algae growth in WSP\#2. The algae likely had a lessening influence on $\mathrm{pH}$ as the weather got colder and it died off. The observation of $\mathrm{pH}$ remaining unbuffered may have been due to the long hydraulic retention times (16 days, 8 days, and 8 days for WSP\#2, WSP\#1, and WSP\#4, respectively) of the WSPs and the die-off of duckweed in WSP\#4.

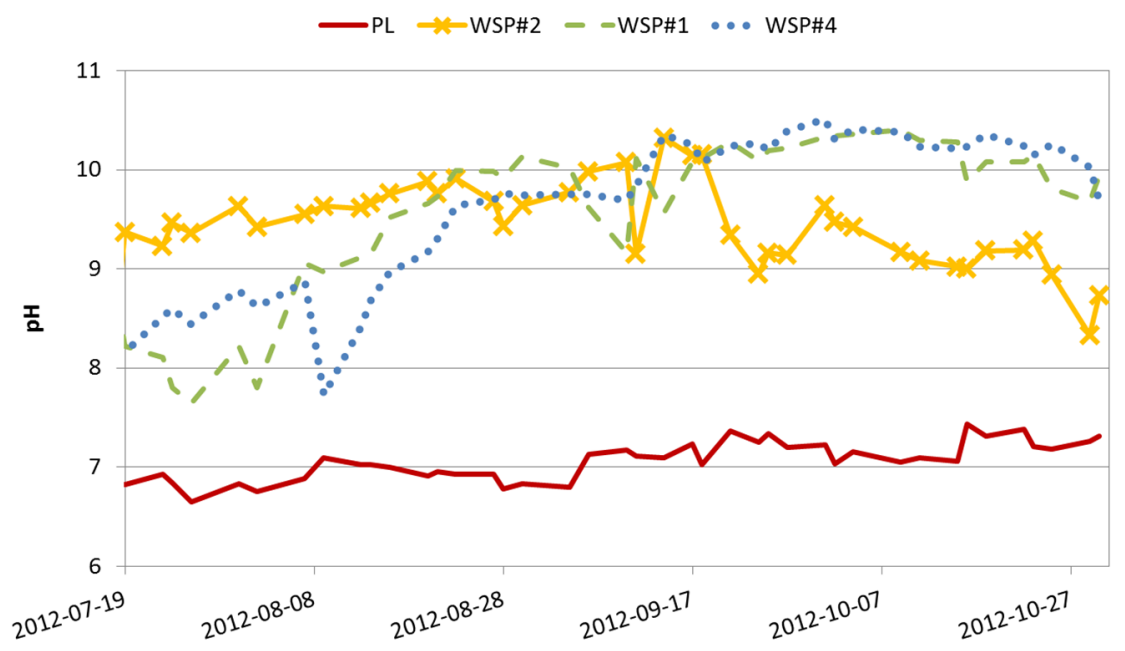

Figure 5. $\mathrm{pH}$ levels in the Amherstview WPCP WSPs over the July to September 2012 sampling period, showing high $\mathrm{pH}$ increases in WSP\#2 that remain high through WSP\#1 and WSP\#4.

The strong negative correlations between $\mathrm{pH}$ and chlorophyceae abundance (Table 5) in WSP\#2 suggest a dynamic time lag between these parameters, wherein the changes of $\mathrm{pH}$ and chlorophyceae abundance are offset by a certain period of time. This was previously identified to be the likely cause of negative correlations between $\mathrm{pH}$ and chl-a in the WSPs during the study period and formed the basis for another study of time series relationships between chl-a, DO, and $\mathrm{pH}$ [38]. The consistent and strong increases in $\mathrm{pH}$ levels and the dominance of chlorophyceae observed in WSP\#2 suggests that algae growth caused $\mathrm{pH}$ levels to rise in the WSPs, with a dynamic time lag between initial algae growth and $\mathrm{pH}$ increases.

To control $\mathrm{pH}$ in the WSPs, two suitable approaches could be undertaken which would involve either reducing the incidence of algae blooms in WSP\#2 or reducing pH levels in WSP\#1 or WSP\#4. 
While algae grow faster than macrophytes, the latter are generally more temperature tolerant $[40,47]$, with duckweed able to grow at temperatures as low as $6{ }^{\circ} \mathrm{C}[40]$ and algae (including chlorophyceae) typically growing at temperatures above $16{ }^{\circ} \mathrm{C}$ [47]. In the spring, the establishment of duckweed populations prior to algae growth could prevent the excessive algae blooms in WSP\#2 historically observed, and stabilize $\mathrm{pH}$ throughout the growth season [46]. In this study, water quality monitoring and metagenomics analysis was initiated mid-summer when algae and macrophyte growth conditions had already been established. Further evaluation and analysis of WSP conditions over the course of spring and early summer, either in simulated laboratory conditions or in the field, may provide more insight into strategies for preventing excessive algae growth in WSP\#2 and promoting duckweed predominance to stabilize $\mathrm{pH}$. Alternatively, $\mathrm{pH}$ could be reduced by physical modifications to WSP\#4, such as through the implementation of a constructed wetland (CW). This design approach is currently being evaluated for the system in a related study. Vegetation in CWs are highly effective at buffering and controlling $\mathrm{pH}$, as noted in a number of studies [52-56]. CWs differ from WSPs in that the wastewater flows, either partially or fully, through layers of gravel or soil media rooted with plants, in addition to areas of open water containing floating and emergent vegetation [8,57].

One potential limitation of our study is the use of 18SrRNA gene dosage to estimate the relative abundance of different algal species, which might lead to an overestimation due to the fact that the $18 \mathrm{~S}$ rRNA gene in algae, just like in most eukaryotic organisms, has variable copy numbers $[58,59]$. However, the study aimed to examine and compare fluctuations in the relative abundances of different species, as opposed to the absolute abundance of each species of algae. It should be noted that for studies where absolute values would be required, metagenomics analysis of $18 \mathrm{~S}$ rRNA gene would not be considered a technique that is robust enough or suitable for such quantification analyses. Hence, in general, caution needs to be taken when drawing strong quantitative conclusions based the findings from the estimation of relative abundances using metagenomics analysis of 18SrRNA gene.

\section{Conclusions}

This metagenomics study of algae and macrophyte species has offered insight into the biological and chemical conditions within the WSPs. In general, green algae of the class chlorophyceae dominated plant growth in WSP\#2 of the system, likely due to the high nitrogen and phosphorus loadings in the influent from the WPCP. Further, the near complete coverage of the water surface by green algae in WSP\#2 likely limited the growth of macrophytes (embryophyta) in this WSP. In WSP\#1, a mixture of green algae and macrophyte growth was observed, suggesting macronutrient conditions favourable to both taxonomic groups and lower nitrogen and phosphorus loadings that limited dominance by green algae. In WSP\#4, macrophytes consisting primarily of duckweed and milfoil, dominated plant growth, likely due to their ability to access nitrogen and phosphorus from sediments under the lower nutrient loadings, and due to their tolerance to higher $\mathrm{pH}$ levels compared to algae. Overall, $\mathrm{pH}$ increases in the system were noted to occur in WSP\#2 as a result of excessive algae growth, and were not stabilized downstream in WSP\#1 and WSP\#4. Metagenomics analysis is a useful technique for identifying plant species growing in WSPs and similar systems and, when coupled with water chemistry parameter analysis, can provide valuable insight into the causes of plant growth and the effect on water quality. 


\section{Acknowledgments}

The authors would like to acknowledge the technical staff at the Queen's Genomics Lab at Ongwanada for their assistance in metagenomics sequencing; Marie-Josée Merritt, Sheila Buck, and Lorie McFarland at Loyalist Township for their assistance with sampling, technical background, and site information. The authors also acknowledge the financial support of the Natural Sciences and Engineering Research Council (NSERC) Collaborative Research and Development (CRD) grant program, NSERC Collaborative Research and Training Experience Program (CREATE) program, and the Canada Research Chair (CRC) program.

\section{Author Contributions}

Jack Wallace, Pascale Champagne, and Geoff Hall conceived and designed the experiments and collected the samples; Xudong Liu and Xhaochu Yin performed the experiments and contributed reagents and analytical equipment; Jack Wallace, Pascale Champagne, Geoff Hall, and Xudong Liu analyzed the data; and Jack Wallace, Pascale Champagne, and Geoff Hall wrote the paper.

\section{Conflicts of Interest}

The authors declare no conflict of interest.

\section{References}

1. Guiry, M.D. How many algae species are there? J. Phycol. 2012, 48, 1057-1063.

2. Natural History Museum. About Algae: The Phyla - Natural History Museum of the UK. Available online: http://www.nhm.ac.uk/research-curation/scientific-resources/biodiversity/uk-biodiversity/ algaevision/about-algae/index.html (accessed on 12 June 2015).

3. Smith, V.H.; Joye, S.B.; Howarth, R.W. Eutrophication of freshwater and marine ecosystems. Limnol. Oceanogr. 2006, 51, 351-355.

4. Ratchford, I.A.J.; Fallowfield, H.J. The effect of light:dark cycles of medium frequency on photosynthesis by Chlorella vulgaris and the implications for waste stabilisation pond design and performance. Water Sci. Technol. 2003, 48, 69-74.

5. Steinmann, C.R.; Weinhart, S.; Melzer, A. A combined system of lagoon and constructed wetland for an effective wastewater treatment. Water Res. 2003, 37, 2035-2042.

6. Zimmo, O.R.; van der Steen, N.P.; Gijzen, H.J. Effect of organic surface load on process performance of pilot-scale algae and duckweed-based waste stabilization ponds. J. Environ. Eng. ASCE 2005, 131, 587-594.

7. Amengual-Morro, C.; Moyà Niell, G.; Martínez-Taberner, A. Phytoplankton as bioindicator for waste stabilization ponds. J. Environ. Manag. 2012, 95, S71-S76.

8. Kayombo, S.; Mbwette, T.S.A.; Katima, J.H.Y.; Ladegaard, N.; Jorgensen, S.E. Waste Stabilization Ponds and Constructed Wetlands Design Manual; United Nations Environment Programme: Osaka, Japan, 2005. Available online: http://www.unep.or.jp/Ietc/WS/publications.asp (accessed on 18 January 2011). 
9. Barsanti, L.; Gualtieri, P. Algae: Anatomy, Biochemistry, and Biotechnology; CRC Press: Boca Raton, FL, USA, 2006.

10. Shammas, N.K.; Wang, L.K.; Wu, Z. Waste stabilization ponds and WSPs. In Biological Treatment Processes, Handbook of Environmental Engineering; Humana Press: Totowa, NJ, USA, 2009; Volume 8, pp. 315-370.

11. Veeresh, M.; Veeresh, A.V.; Huddar, B.; Hosetti, B.B. Dynamics of industrial waste stabilization pond treatment processes. Environ. Monit. Assess. 2010, 169, 55-65.

12. Amherstview Water Pollution Control Plant-Operating Manual; CH2M Gore and Storrie Limited: Toronto, ON, Canada, 1997.

13. QIAGEN. DNeasy Plant Mini Kit. Available online: http://www.qiagen.com/products/catalog/ sample-technologies/dna-sample-technologies/genomic-dna/dneasy-plant-mini-kit (accessed on 12 October 2013).

14. Sherwood, A.R.; Presting, G.G. Universal primers amplify a 23s rDNA plastid marker in eukaryotic algae and cyanobacteria. J. Phycol. 2007, 43, 605-608.

15. Stiller, J.W.; McClanahan, A.N.A. Phyto-Specific 16S rDNA PCR primers for recovering algal and plant sequences from mixed samples. Mol. Ecol. Notes 2005, 5, 1-3.

16. Cuvelier, M.L.; Allen, A.E.; Monier, A.; McCrow, J.P.; Messié, M; Tringe, S.G.; Woyke, T.; Welsh, R.M.; Ishoey, T.; Lee, J.-H.; et al. Targeted metagenomics and ecology of globally important uncultured eukaryotic phytoplankton. Proc. Natl. Acad. Sci. USA 2010, 107, 14679-14684.

17. Ghai, R.; Hernandez, C.M.; Picazo, A.; Mizuno, C.M.; Ininbergs, K.; Díez, B.; Valas, R.; DuPont, C.L.; McMahon, K.D.; Camacho, A.; et al. Metagenomes of mediterranean coastal lagoons. Sci. Rep. 2012, 2, 490-502.

18. Kim, K.M.; Park, J.H.; Bhattacharya, D.; Yoon, H.S. Applications of next-generation sequencing to unravelling the evolutionary history of algae. Int. J. Syst. Evol. Microbiol. 2014, 64, 333-345.

19. Somboonna, N.; Wilantho, A.; Assawamakin, A.; Monanunsap, S.; Tangphatsornruang, S.; Sangsrakru, D.; Tongsima, S. Structural and functional diversity of free-living microorganisms in reef surface, Kra island, Thailand. BMC Genomics 2014, 15, 607-620.

20. Worden, A.Z.; Janouskovec, J.; McRose, D.; Engman, A.; Welsh, R.M.; Malfatti, S.; Tringe, S.G.; Keeling, P.J. Global distribution of a wild alga revealed by targeted metagenomics. Curr. Biol. 2012, 2, R675-R677.

21. Life Technologies. Ion PGM Template OT2 200 Kit. Available online: http://www.life technologies.com/order/catalog/product/4480974 (accessed on 12 October 2013).

22. Life Technologies. 2013. Available online: http://www.lifetechnologies.com/order/catalog/ product/4474004 (accessed on 12 October 2013).

23. American Public Health Association (APHA). Standard Methods for the Examination of Water and Wastewater; APHA: New York, NY, USA, 2005.

24. QIIME. 2013. Available online: http://qiime.org/ (accessed on 13 October 2013).

25. Lozupone, C.; Knight, R. UniFrac: A new phylogenetic method for comparing microbial communities. Appl. Environ. Microbiol. 2005, 71, 8228-8235.

26. Lozupone, C.; Lladser, M.E.; Knights, D.; Stombaugh, J.; Knight, R. UniFrac: An effective distance metric for microbial community comparison. Int. Soc. Microb. Ecol. J. 2011, 5, 169-172. 
27. Fielding, A. MDS or Principal Components Analysis; Manchester Metropolitan University: Manchester, UK, 2013. Available online: http://www.alanfielding.co.uk/multivar/pco.htm (accessed on 13 October 2013).

28. Simpson, M.G. Plant Systematics; Elsevier/Academic Press: Amsterdam, The Netherlands, 2006.

29. Integrated Taxonomic Information System (ITIS). Myrophyllum. Available online: http://www. itis.gov/servlet/SingleRpt/SingleRpt?search_topic=TSN\&search_value=27034 (accessed on 4 June 2013).

30. Integrated Taxonomic Information System (ITIS). Lemna. Available online: http://www.itis.gov/ servlet/SingleRpt/SingleRpt?search_topic=TSN\&search_value=42588 (accessed on 4 June 2013).

31. Integrated Taxonomic Information System (ITIS). Potamogeton. Available online: http://www.itis. gov/servlet/SingleRpt/SingleRpt?search_topic=TSN\&search_value=39005 (accessed on 4 June 2013).

32. Landesman, L.P.C.; Fedler, C.B.; Konikoff, M. Modeling duckweed growth in wastewater treatment systems. Livest. Res. Rural Dev. 2005, 17, 61.

33. Sterner, R.W.; Grover, J.P. Algal growth in warm temperate reservoirs: Kinetic examination of nitrogen, temperature, light, and other nutrients. Water Res. 1998, 32, 3539-3548.

34. Kayombo, S.; Mbwette, T.S.A.; Katima, J.H.Y.; Jorgensen, S.E. Effects of substrate concentrations on the growth of heterotrophic bacteria and algae in secondary facultative ponds. Water Res. 2003, 37, 2937-2943.

35. Mesplé, F.; Casellas, C.; Troussellier, M.; Bontoux, J. Modelling orthophosphate evolution in a high rate algal pond. Ecol. Model. 1996, 89, 13-21.

36. Tchobanoglous, G.; Burton, F.L.; Stensel, H.D. Wastewater Engineering: Treatment and Reuse; McGraw-Hill: Dubuque, IA, USA, 2003.

37. Urgun-Demirtas, M.; Sattayatewa, C.; Pagilla, K.R. Bioavailability of dissolved organic nitrogen in treated effluents. Water Environ. Res. 2008, 80, 397-406.

38. Wallace, J.; Champagne, P.; Hall, G. Multivariate Statistical Analysis of Water Chemistry Dynamics in Three Facultative Wastewater Stabilization Ponds with Algae Blooms and pH Fluctuations. Master's Thesis, Queen's University, Kingston, ON, Canada, 27 October 2013.

39. Govindjee, R. What is Photosynthesis? University of Illinois at Urbana-Champaign, Urbana, IL, USA. Available online: http://www.life.illinois.edu/govindjee/whatisit.htm (accessed 11 June 2013).

40. Leng, R.A. Duckweed: A Tiny Aquatic Plant with Enormous Potential for Agriculture and Environment; United Nations Food and Agriculture Organization: Rome, Italy, 2003. Available online: http://www.fao.org/ag/againfo/resources/documents/DW/Dw2.htm (accessed on 11 June 2013).

41. Tan, R. Duckweed: Mangrove and wetland wildlife at Sungei Buloh Natural Park. Available Online: http://www.naturia.per.sg/buloh/plants/duckweed.htm (accessed on 11 June 2013).

42. Bristow, J.M.; Whitcombe, M. The Role of roots in the nutrition of aquatic vascular plants. Am. J. Bot. 1971, 58, 8-13.

43. Madsen, T.V.; Cedergreen, N. Sources of nutrients to rooted submerged macrophytes growing in a nutrient-rich stream. Freshw. Biol. 2002, 47, 283-291.

44. Barko, J.W.; Gunnison, D.; Carpenter, S.R. Sediment interactions with submersed macrophyte growth and community dynamics. Aquat. Bot. 1991, 41, 41-65.

45. Keffala, C.; Harerimana, C.; Vasel, J.-L. A review of the sustainable value and disposal techniques, wastewater stabilisation ponds sludge characteristics and accumulation. Environ. Monit. Assess. 2013, 185, 45-58. 
46. Kesaano, J. Sustainable Management of Duckweed Biomass Grown for Nutrient Control in Municipal Wastewaters. Master's Thesis, Utah State University, Logan, UT, USA, 2011. Available online: http://digitalcommons.usu.edu/cgi/viewcontent.cgi?article $=1875 \&$ context $=$ etd (accessed on 18 June 2013).

47. United Nations Food and Agriculture Organization (FAO). Manual on the Production and Use of Live Food for Aquaculture; Lavens, P., Sorgeloos, P., Eds.; FAO: Rome, Italy, 1996. Available Online: http://www.fao.org/docrep/003/w3732e/w3732e00.htm\#Contents (accessed on 18 June 2013).

48. Bergstrom, C.M.; Patel, S. Effects of pH on Algal Abundance: A Model of Bay Harbor, Michigan; University of Michigan: Ann Arbor, MI, USA, 2007. Available online: http://deepblue.lib.umich.edu/ bitstream/handle/2027.42/57443/Bergstrom_McKeel_Patel_2007.pdf?sequence=1 (accessed on 18 June 2013).

49. Crites, R.W.; Tchobanoglous, G. Small and Decentralized Wastewater Management Systems; WCB/McGraw-Hill: Boston, MA, USA, 1998.

50. Zang, C.; Huang, S.; Wu, M.; Du, S.; Scholz, M.; Gao, F.; Lin, C.; Guo, Y.; Dong, Y. Comparison of relationships between $\mathrm{pH}$, dissolved oxygen and chlorophyll a for aquaculture and non-aquaculture waters. Water Air Soil Pollut. 2011, 219, 157-174.

51. Zimmo, O.R.; Al Saed, R.; Gijzen, H. Comparison between algae-based and duckweed-based wastewater treatment: Differences in environmental conditions and nitrogen transformations. Water Sci. Technol. 2000, 42, 215-222.

52. Wallace, J.; Champagne, P.; Hall, G. Time-Series relationships between chlorophyll-a, dissolved oxygen, and $\mathrm{pH}$ in three facultative wastewater stabilization ponds. Water 2015, under review.

53. Gschlöß1, T.; Steinmann, C.; Schleypen, P.; Melzer, A. Constructed wetlands for effluent polishing of lagoons. Water Res. 1998, 32, 2639-2645.

54. Mayes, W.M.; Aumonier, J.; Jarvis, A.P. Preliminary evaluation of a constructed wetland for treating extremely alkaline ( $\mathrm{pH}$ 12) steel slag drainage. Water Sci. Technol. 2009, 59, 2253-2263.

55. Mayes, W.M.; Batty, L.C.; Younger, P.L.; Jarvis, A.P.; Kõiv, M.; Vohla, C.; Mander, U. Wetland treatment at extremes of pH: A review. Sci. Total Environ. 2009, 407, 3944-3957.

56. Tsalkatidou, M.; Gratziou, M.; Kotsovinos, N. Combined stabilization ponds-constructed wetland system. Desalination 2009, 248, 988-997.

57. Vymazal, J.; Greenway, M.; Tonderski, K.; Brix, H.; Mander, Ü. Constructed wetlands for wastewater treatment. In Wetlands and Natural Resources Management, Ecological Studies; Springer: Berlin/Heidelberg, Germany, 2006; pp. 69-96.

58. Zhu, F.; Massana, R.; Not, F.; Marie, D.; Vaulot, D. Mapping of picoeucaryotes in marine ecosystems with quantitative PCR of the 18S rRNA gene. FEMS Microbiol. Ecol. 2005, 52, 79-92.

59. Gong, J.; Dong, J; Liu, X.; Massana, R. Extremely high copy numbers and polymorphisms of the rDNA operon estimated from single cell analysis of oligotrich and peritrich ciliates. Protist 2013, $164,369-379$.

(C) 2015 by the authors; licensee MDPI, Basel, Switzerland. This article is an open access article distributed under the terms and conditions of the Creative Commons Attribution license (http://creativecommons.org/licenses/by/4.0/). 